\title{
W. Keim
}

\section{Social sciences internationally: The problem of marginalisation and its consequences for the discipline of sociology}

\section{Introduction}

The development of sociology in Africa and Latin America has remained largely under-researched until now. Ongoing debates on the globalisation of economy and society, as well as the increasingly cross-national activities of the scholarly community, have been enhancing reflections on the internationalisation or globalisation of the discipline, a topic on the agenda of each of the more recent World Congresses of Sociology. Diverging perceptions of these processes within sociology have been articulated, opposing those who argue for the internationalisation or globalisation of the discipline without explicitly insisting on present North-South divides (Albrow/King 1990; Archer 1991; Genov 1991) on the one hand, and those who insist on the disadvantaged position of, for instance, African (Adésínà 2002) or Indian (Oommen 1991) sociologies, on the other hand. The debate around the globalisation of sociology, political and often polemical at first sight, illustrates the increasingly difficult articulation between the universalistic claims of the discipline as such and its particular developments locally or nationally (Berthelot 1998; Keim 2006), and is thus of epistemological importance as well.

Strongly theoretical and often highly politicised, however, this debate more often than not lacks an adequate empirical basis. The main objective here is to take up systematically the several dimensions and factors of the centre-periphery-divide that have been mentioned in the literature so far. ${ }^{1}$ Subsequently, a variety of factors relating more specifically to the problem of marginalisation will be tested empirically. The paper will thus provide a systematisation of dispersed elements mentioned in the fields of science studies, including the history of science and knowledge, on the one hand; the sociological debate around the globalisation of the discipline, on the other hand. It will be argued that the underlying structure that links dispersed results in these two fields can be captured through an analytical centre-periphery-model. The relevance of the results for current science policy as well as for the epistemological foundations of sociology will be shortly reflected upon in the conclusion.

\section{Centre-Periphery Models in history and sociology of science literature}

The starting point of this paper is the hypothesis that a centre-periphery-model seems to be a valid tool for the description and comprehension of processes of social scientific knowledge production, diffusion, reception and scholarly communication at an international level. From a global perspective, sociologies in Western Europe and the United States appear to constitute the centre of our discipline, whereas those from the global South, despite claims for the internationalisation and globalisation of the discipline, occupy today a rather peripheral position. There are a number of reasons for 
and multiple manifestations of the hierarchical relationship between scholarly communities, their institutions and their research output.

One important reason is that, historically, sociology as a specific scholarly discipline, as opposed to social thinking, which is probably as old as humankind and present all over the globe, emerged and was institutionalised in Europe first - Ibn Khaldun's (1967-68) early attempt to found a 'science of civilisation' had full potential but found few followers. ${ }^{2}$ A series of studies in history of the sciences points out how the modern scientific system expanded through colonialism and imperialism, using a centre-periphery-model for science history (Baber 2003, Mignolo 2004, Petitjean/Jami/Moulin 1992, Polanco 1992, Rashed 1992, MacLeod 1982; for specific case studies, see Saldaña 1992, Krishna 1992, Todd 1993). Similarly, sociology in the southern continents as well emerged as a subordinated, dependent sociology.

After decolonisation, the structures of scientific dependency more often than not remained intact. Many scholars from southern countries still study and get their Ph.D.s in European metropolises, while the United States as the new centre of the international scientific system has also had considerable impact on the development of sociologies particularly in Africa, Latin America and India, partly because of their encouragement of US-style social sciences as an ideological weapon in times of the Cold War (Gareau 1985, Chekki 1987).

Several authors address these current issues in terms of centre-periphery. Hountondji links the present situation of the sciences in the global South to historical subordination. Drawing on dependency and world systems theory, he understands underdevelopment in the South as a consequence of their historical annexation to the world market and transposes this explanatory scheme to the domain of scientific development (Hountondji 1990b: 7. See also: Hountondji 1994: 2).

Although this paper will follow his invitation to draw analogies between the functioning of the economic and the academic domains, it appears that this can not account for all problems the centre-periphery-divide represents for the social sciences. Gareau's article 'The multinational version of social science with emphasis upon the discipline of sociology' (Gareau 1985) is one of the few attempts to study the international relations within sociology applying science study methodology. In his own centre-periphery model, Gareau distinguishes three social scientific 'blocs': Western social science in the US and Western Europe, Soviet Marxism-Leninism, and the peripheral social sciences of the South. He bases his assumption that the three blocs communicate in hierarchical relationships on empirical evidence. He thus states the ethnocentric perspective of Western social science and the intellectual dependency and subordination of the South, as well as the unilateral communication in hierarchical relationships.

Gareau denominates the different scholarly communities, according to their paradigmatic orientation and national location, as 'sects'. The vocabulary indicates his critical and relativistic attitude towards what he calls 'multinational social science'. Thus, he assumes a purely external determination of the observed intellectual hegemony: US-American social science is not that widely spread and recognized because of its 'intrinsic values', but because of the political, economic and cultural domination of the US. According to Gareau, social scientific power corresponds to and relies on economic and political power, because the social sciences are part of the 
'knowledge industry'. Sociology, the discipline he focuses on, is thus apprehended as being totally determined by external interests.

As Gareau's article proposes a macro-sociological approach to the international relations within the discipline, it will be one of the starting points for the model presented below. However, the limitations of his proposition should also be pointed out. First of all, his article bears the marks of the Cold War period and therefore calls for some revisions today. What is more problematic, however, is his unilateral economic and geopolitical determinism. This perspective neglects the fact that institutional and material factors within academia cannot be exclusively reduced to the broader economic situation. For instance, if the US-American social sciences are characterized as the most ethnocentric ones and as forming a practically closed and self-referent communication system, largely ignoring the rest of the world, the geopolitical position of the US alone does not seem to be a satisfactory explanation in itself. Rather, it has also to be taken into account that the US-American social sciences are among the most developed of the world and their scholarly community is probably the largest. This means there is a sufficient critical mass within the country that ensures scholarly discussion and the subsequent development of the discipline. External communication is thus not of the same, vital importance as in smaller communities.

Other factors that Gareau certainly underestimates are the power position of the US in the publications sector and in the domain of international bibliographic databases, as well as the effects of the disciplinary division of the social sciences, topics that will be examined below. If these factors do not necessarily contradict Gareau's assumption at a more abstract level, they need to be dealt with in more detail in order for us to understand the specific functioning of the social sciences internationally.

Several other authors provide ideas and empirical evidence referring to single aspects of the centre-periphery divide, for instance S. F. Alatas $(2001,2003)$ and S. H. Alatas $(1974,2006 a, 2006 \mathrm{~b})$ who have focussed more particularly on sociology. Others have provided empirical indicators on the peripheral situation of the sciences in the continents of the South (Arvanitis/Gaillard 1992, Waast 1996, 2001, Waast/ Gaillard 1996 and Weingart 2004), but neglected the domain of the social sciences and have not emphasised the conceptualisation of an analytical centre-periphery model. These contributions will be integrated into the model presented below, which has the advantage of systematizing the relevant literature, much of which remains actually dispersed geographically, disciplinarily and paradigmatically, into a broader comprehensive picture. Furthermore, the proposed model has the potential to be operationalised for empirical testing.

\section{For an analytical centre-periphery model in the study of the social sciences internationally}

One of the innovative aspects of the centre-periphery approach at the point of time of its emergence was its conceptualisation of the relationships between and the reciprocal conditioning of the global centre and periphery. The three-dimensional model that has been developed within dependency theory for the global expansion of capitalism (Cardoso/Faletto 1969) can be transposed to the domain of the social sciences, in only partial analogy, for sure, as we are dealing here not with material goods but with ideas, knowledge and discourses. ${ }^{3}$ Three dimensions have thus to be distinguished for the 
sake of analytical clarity, as represented in the following schematisation:

\begin{tabular}{|c|c|c|}
\hline Centre & $\begin{array}{l}\text { I. Infrastructure and Internal } \\
\text { Organisation }\end{array}$ & Periphery \\
\hline Development & & Underdevelopment \\
\hline & $\begin{array}{l}\text { II. Conditions of Existence } \\
\text { and Reproduction }\end{array}$ & \\
\hline Autonomy & & Dependency \\
\hline & $\begin{array}{l}\text { III. International Position } \\
\text { and Recognition }\end{array}$ & \\
\hline Centrality & & Marginality \\
\hline
\end{tabular}

First of all, scientific development requires an appropriate material, institutional and personal basis. Lack of the necessary material infrastructure (Waast 2001, Bako 1994, 2002), but also suppression of academic freedom (Diouf/Mamdani 1994) in parts of the global South - especially in a number of African countries - seem to be major causes for the peripheral status of their sociologies. An ideal-typical developed sociology shows a high degree of institutionalisation, with specialised centres for research and teaching, journals and associations. Institutional development requires sufficient funding and adequate income opportunities for researchers, as well as a broader academic institutional framework and further infrastructures such as editing houses, a book market, information and communication technologies, well equipped libraries etc. Furthermore, a developed sociology is characterised by its internal division of labour that covers and continuously develops all domains of sociological activity from empirical data collection and the realisation of case studies at a low level of abstraction to conceptualisation, methodology and theory building. It therefore requires a functioning scholarly community that constantly communicates, cooperates and critically discusses results, in a thematic as well as cognitive division of labour. Furthermore, the scholarly community determines and maintains the requirements for accession and exclusion from the profession - curriculum development, teaching contents, examination and certification. A developed sociology can thus be defined as a system of autonomous production, diffusion and accumulation of knowledge and discourses. Consequently, an underdeveloped sociology lacks one or several of the above mentioned characteristics. This first dimension, social-scientific development, is mainly determined by external factors such as availability of funding, scientific and higher education infrastructures.

But the historically evolved hierarchies and inequalities in the production, diffusion, and especially reception of social scientific knowledge remain intact even in countries with comparably strong local social sciences (for example, the case of Japan: Koyano 1976, Lie 1996). A second dimension of the centre-periphery problem, often but certainly not always related to the state of development and to be analytically distinguished from it, is that referring to the conditions of existence of given sociologies, namely the dimension of autonomy or dependency. 
An autonomous sociology has the capacity of self-reproduction and autonomous development at the level of its staff, institutions and knowledge. Research results are communicated internally and can be diffused into other communities. On the opposite side, dependent sociology requires a steady import of theories and concepts, teaching material and research devices as well as of academic degrees from the universities of the centre. It relies on a methodological-theoretical as well as personal basis which it hardly contributes to produce. Autonomy is not to be confused with autarchy, in the sense that scholarly activity is in itself always internationally constituted. The difference lies in the fact that autonomous sociology benefits from international exchange and communication, whereas these are an essential requirement for dependent sociology.

While the impact of financial dependency on overseas resources is not always easy to determine, it seems obvious that problems related to editorial dependency (Altbach 1991) as well as over-reliance on overseas certification, especially at the $\mathrm{PhD}$ level (Szanton/Manyika 2002), and most of all to intellectual dependency, i.e. receiving and applying concepts, theories and methodologies developed in the centre, are today inhibiting the emergence of autonomous sociological approaches and traditions. They have been aptly described by S. H. Alatas (1974, 2006a, 2006b), S. F. Alatas (2001, 2003) and Hountondji (1990a, 1990b, 1994). Unfortunately, due to methodological constraints, the dimension of autonomy/dependency can hardly be evaluated on a macro-level; it would necessitate in-depth content analyses of sociological output with regard to the reception of theoretical framework, methodology, the origin of key concepts and the literature considered (for examples of in-depth text analysis of South African sociological literature with regard to degrees of dependency, for example in citation schemes, see Keim forthcoming b: 391-459). Relevant information to evaluate the degree of dependency - such as the origin of degrees obtained by the teaching staff and researchers, the origin of books in their libraries and on course outlines, the central references in sociological texts - is not systematically available on a large-scale basis. This second dimension - autonomy or dependency - refers to intra-scientific factors in the first place.

This article focuses on the third dimension of the problem: the question of centrality and marginality, an intra-scientific problem referring to the position and function of given sociologies within the international community. The terms centrality and marginality are used here to describe the relationship between existing communities, their institutions and scholarly production.

Centrality refers to internationally visible sociologies that enjoy prestige in the international community and that are recognised as the core of the discipline. This applies to their institutions and scholarly authorities, teaching programmes and degrees, prestigious journals and editing houses. Their particular position confers on them the power of setting the dominant topics of research and teaching, methodological and theoretical approaches, as well as meta-discourses. In other words, they establish what could be referred to as schools, paradigms, ideologies, etc. Referring to a phenomenon of mutual recognition, definitions of marginal and central science are always somewhat tautological. Central science is often defined as the mainstream in the sense of the international bibliographic databases (Gaillard 1987: 9; Arunachalam 1996). But these databases are the mainstream and they set the 
mainstream at the same time (see below). Alatas, referring to Gizyncki, defined the centre as 'a place from which influence radiates', which is no less tautological but a logical problem inherent to the concept (S. F. Alatas 2003: 603).

The hypothesis of the chosen centre-periphery model is that today African and Latin American sociologies, like these continents' intellectual production in general, occupy a marginal position within the international scholarly community. They lack international recognition, and not only are they largely ignored in the rest of the world, but that ignorance is not even considered to be a problem. They rely on the institutions and scholarly production of the centre, either because they have no local alternative in this case marginality combines with underdevelopment and dependency - or because they remain oriented, despite local alternatives, to locations in the international field that are regarded as more prestigious.

The following will take up systematically a series of factors and manifestations of marginalisation that are mentioned, often in rather polemical ways, in the literature: lack of visibility in international databases, forms and dimensions of the unequal division of social scientific labour, problems of extraversion, locality and exoticism, the effects of the disciplinary divisions within the social sciences, as well as of the evolutionism inherent in social thinking. Finally, central social sciences study the societies of the periphery, whereas marginal ones do not deal with the societies of the centre as an object of study.

It should be stressed that marginality and centrality as conceptualised here have analytical value in the first place and are not meant as a value judgement. Furthermore, the macro-sociological focus, characterising the relationship between national and even continental scholarly communities, does not mean that dynamics of marginalisation on a more meso- or micro-sociological level - within regional, national and local scientific communities as well as within single institutions - should be underestimated. These phenomena are not the subject of this article.

The paper thus pulls together and exposes in a systematic way arguments and evidence on the topic, providing genuine empirical data where necessary, and will thus give a more complete picture of the complexity and extent of the problem of marginalization within sociology.

It should be emphasised that the proposed model renounces the category of 'semiperipheries'. Instead, the analytical distinction of three dimensions of centre and periphery allows for a more detailed description of particular cases. For instance, to cite two cases dealt with in the literature, Japan could be characterized as hosting a highly developed, yet strongly dependent and rather marginal sociology, whereas in Palestinian sociology, the underdevelopment factor appears to be the main reason for its peripheral position internationally (Cf. for these examples Koyano 1976, Lie 1996, Tamari 1994, Romani 2008). We could even think of cases where original thinkers develop theoretical approaches that earn international recognition despite academic underdevelopment, often outside academia. The theoretical debates surrounding the African liberation struggles (Fanon 1961, 1968, Cabral 1973, 1983, Magubane 1983 etc.) can be mentioned here as an example that challenges the established view of the necessity of solid academic institutions as a basis for theoretical developments. 


\section{International bibliometric databases - indicators of marginality and instruments of marginalisation}

A common method for measuring the contribution of individual scholars or of given scientific communities to the advancement of their disciplines is scientometry, especially bibliometry. Pouris (1995), for instance, applies this methodology to the study of social sciences internationally, stating that 90 percent of the articles contained in the 'Social Science Citation Index' originate in 10 percent of the world's countries. He erroneously interprets this result as representing the percentage of the international social scientific production. However, this conventional usage of bibliometric databases to determine scholarly production is highly questionable, especially with regard to the countries of the global South (Cf. Frame 1985; Arvanitis/Gaillard 1992). In fact, they cover by definition those products of scholarly labour that have already had considerable 'international impact', i.e. the most frequently cited ones, thus creating a vicious circle where only those that are already recognised have the chance to gain even higher visibility (Barré/Papon 1993: 328). Analyses of these databases with regard to the origin of articles show that the included scholarly production is highly concentrated geographically and thus can serve as an indicator for centralitymarginality. Keeping in mind the numerous sources for errors, which bibliometric analyses can hardly avoid, an evaluation of the visibility of national social science literature nevertheless produces crucial results.

The Social Sciences Citation Index covers literature from '1 700 of the world's most significant social science journals' ${ }^{4}$ The search field 'Author Address' provides the possibility to search for all the articles published by authors institutionally affiliated in a given country.

The realities of a highly stratified international community are more than obvious when the following are considered: the SSCI contains 366,828 articles by authors and co-authors affiliated in the United States, which is 58 percent of the total of the covered literature, followed by Great Britain $(71,606)$ and Canada $(40,573)$. North America thus represents 64 percent of all the entries whereas Western Europe, including Austria, Belgium, Denmark, Finland, France, Germany, Greece, Great Britain, Iceland, Ireland, Italy, Luxemburg, the Netherlands, Norway, Portugal, Spain, Sweden and Switzerland, totals 25 percent. On the other hand, literature from the whole of the African continent amounts to less than one percent. Within Africa, South Africa is the most important country $(2,762)$, followed by Nigeria (667). Out of the 49 African nations, only ten had more than 100 articles referenced in the SSCI. The whole of Latin America equals about one percent with Brazil $(1,793)$ and Mexico $(1,630)$ at the top, followed by Jamaica (721). Out of the 26 Latin American countries, eight appear more than 100 times as countries of author affiliation.

The database FRANCIS (1984-2005) could be considered as the French counterpart to the SSCI. ${ }^{5}$ A search according to countries of authors' affiliation provided useful data.

FRANCIS proves to be slightly more balanced than the SSCI: 44 percent of all articles were published by authors affiliated to US-American institutions $(310,734)$. Together with those from Canada $(49,441), 51$ percent of all covered publications originated in North America, 34 percent in Western Europe. In line with linguistic priorities, France occupies the second position worldwide $(108,557)$, followed by 
Great Britain $(80,447)$ and Germany $(44,505)$. Articles by authors from African institutions again only represent a small fraction of approximately 1.5 percent, and those from their Latin American counterparts approximately 2.3 percent.

The database 'Sociological Abstracts' (1995-2005) concentrates especially on sociological literature. Unfortunately, however, the global share of the US could not be determined for Sociological Abstracts, due to the fact that author addresses in the United States do not indicate the country. As a consequence, the relationships between all remaining countries also shift with the distribution and seem to be more egalitarian at first.

For the last decade, Great Britain occupied the first place $(19,592)$, followed by Australia $(5,456)$, Germany $(5,304)$ and France $(4,583)$. To account for the effect of the exclusion of the major power, however, it is noteworthy to differentiate some of the US-based articles by city or region of origin. For the last decade, the database covers 8,134 articles published by authors employed in California, which thus occupies the second position worldwide, 5,927 by authors affiliated in New York, and 3,774 by scholars from Washington, just to pick a few examples. African production makes up approximately 3.3 percent with a total number of 2,427 articles, approximately equalling that of Italy or Chicago. Latin American countries have 8.5 percent of the entries as 'author affiliation'. Consequently, this database is not more balanced than the other two.

Instead of erroneously taking these results as the reflection of scholarly production, they should be understood as indications of the degree of centrality or marginality of given national communities. This becomes very obvious in the case of China. According to UNESCO, China was the first country in the publication of social science books (55,380 titles) (UNESCO 1999b). ${ }^{6}$ This productivity is not reflected in the considered databases at all. The producers of bibliometric databases, through their criteria of selection, determine which social sciences are central and constitute the mainstream, and which are supposedly of no interest to the international community. Insofar they have to be understood as an indicator of marginality and at the same time as an instrument of marginalisation, strengthening North Atlantic domination.

Nevertheless, the analysis so far does not exclude the possibility that low figures for the African and Latin American continents correspond to real underdevelopment in the scholarly publication sector and thus do correlate to de facto scholarly production. A response to that question must remain unsatisfactory, as one cannot rely on any alternative source for objective figures on publication output. However, UNESCO provides a small database, DARE, containing social sciences journals from all over the world (http://www.unesco.org/most/dare.htm, June 2003). DARE is neither complete, nor representative, and the person in charge at the office in Paris could not even explain on which grounds journals are included in DARE (personal communication, Sept. 2003). Compared with the entries in the so-called 'international databases', the titles in the UNESCO database can therefore be regarded as a kind of random sample of social sciences journals. For matters of convenience, only African journals, production and referencing are examined more closely here.

DARE contains 280 African journals, most of which have existed for several years or decades, their longevity indicating to some extent their degree of establishment within the regional and local social sciences and insuring that one is not confronted 
with the 'Volume One, Number One' syndrome (cf. on development problems in African journal production: Adebowale 2001). Out of these 280, the SSCI (1992-1997) covers only two: the South African Journal of Economics and African Studies (also from South Africa). The marginalisation of African journal production in this database is blatant. FRANCIS (1984-2005) seems to be slightly more representative, covering 32 of the 280 journals - one Egyptian, one Malian, two Nigerian and Senegalese, three Algerian, Kenyan and Moroccan, four Congolese, five Tunisian and eight South African journals. Nevertheless, the large majority of the titles remain invisible in FRANCIS as well. Sociological Abstracts includes 23 of the African journals contained in DARE for the period 1960-2005: one from the Ivory Coast, Ghana and Tunisia, two from Kenya, Nigeria, Senegal and Zimbabwe, twelve from South Africa. Although slightly more balanced than the SSCI, it does not even cover 10 percent of the random sample.

Furthermore, this brief survey exposes a lack of consensus as to which African journals rank among 'the world's most significant' ones: only one title is included in all three considered databases (SSCI, FRANCIS, Sociological Abstracts), the South African African Studies, which also indicates the regionally specialised interest for African social sciences (see below). The fact that both SSCI and FRANCIS ignore two of the long standing and probably most prestigious journals of the continent, CODESRIA's Africa Development and the former South African Sociological Review, today African Sociological Review, edited by CODESRIA as well, should undermine their credibility at least in the African research community. On the other hand, popular but not peer-reviewed journals like the South African Labour Bulletin appear in one of the databases, which shows once more the common ignorance of the African publication sector in Philadelphia, Cambridge and Paris alike.

The bibliometric analysis thus confirms the hypothesis that African social sciences production is highly marginalised within the international mainstream. A similar but probably more complete cross-checking of the so-called international databases will soon be possible for Latin America, which is currently establishing its own alternative international data base, the LATINDEX. ${ }^{7}$ The results could be complemented by considerations of the language factor or the composition of editorial committees, i.e. the positions of power within the international social sciences journals (Cf. Schubert/ Braun, 1996). This paper will not examine these possible extensions of bibliometric analysis but instead mentions a few other, maybe less obvious indicators and factors, of marginalisation.

\section{The unequal global division of social scientific labour}

Marginality also refers to the function that scholarly communities perform within global knowledge production. Hountondji points to an unequal global division of labour, which dates back to the colonial period and parallels economic and geopolitical centre-periphery structures (Hountondji 2001/02). S. F. Alatas differentiates three levels: ' 1 . The division between theoretical and empirical intellectual labour. 2.) The division between other country studies and own country studies. 3.) The division between comparative and single case studies' (Alatas 2003: 607). According to the generally accepted hierarchies of knowledge (Cf. Gaillard/Schlemmer 1996: 128), the social sciences of the global South produce mainly knowledge at the lower levels, in 
the sense that they deal with local problems at a low level of abstraction and generalisation, whereas the North holds almost a monopoly on prestigious comparative research and general theory building, i.e. the more universalising social sciences knowledge (Sitas 2006). ${ }^{8}$

This unequal division manifests itself at institutional and personal levels, for example regarding cooperation programmes. In his programme for a Mexican social sciences research policy, González Casanova emphasised the crucial question of international cooperation and summarised a few rules to be respected in such collaboration to enhance the local social sciences: the Mexican researchers should be integrated in all stages of research, from conceptualisation to the publication of the results, and should not remain limited to collecting data; the theoretical framework and the initial hypothesis should be published; the results should be analysed and published in Mexico first and only subsequently abroad; as partners in international comparative projects, the Mexican researchers should participate in the whole of the analysis and interpretation and should have access to all materials from all regions part of the comparison; no region should be excluded as an object of research; organisation and development of the research and the practical research experience obtained should be published together with the results (González Casanova 1968: 26). The author thus highlights several points that have proven to play their part in the unequal division of labour at the level of personal and institutional collaborations.

In his introduction to a compilation of articles on international scientific cooperation, Gaillard generalises the main problem in North-South-relations as the existing hierarchy between the participants: '(...) all the authors who have contributed to this volume agree that the main problems in the practice of North-South collaboration programmes are tied to the asymmetry in collaboration and to the domination that the partners from the North exert' (Gaillard 1996: 12. Translation W.K. For further details and case studies see: Gaillard 1999). The mentioned hierarchies refer to the fact that the Northern partners were more involved in the central tasks of conceptualisation, interpretation, theory building and publication, whereas the Southern colleagues often had to contend themselves with collecting and processing data. Empirical research on North-South-inequalities in scientific collaborations - not distinguishing between disciplines - showed that in 90 out of 100 cases, the head office of the cooperation projects was with an institution in the North. In 65 percent, the initiative for research also emanated from there (Gaillard/Schlemmer 1996: 124). In a series of interviews with African researchers, Waast observed that: ' $($... the researchers who benefit from cooperation programs complain about being subjected to a narrow agenda and about an unequal division of labour. Many of them estimate that their role is limited to that of mere suppliers of data, or of developers of solutions devised out of context, following a standardised model' (Waast 2002: 43. See also Teferra 2002).

This problem is also well known among African social scientists (Hountondji 1990, 1994, 2001/02, Sitas 2006), and Mkandawire considers it to be of particular importance, also referring to the fact that it is mostly regional specialists who are interested in social scientific research in and on Africa (Mkandawire 1989: 2). This issue is examined in the next paragraph. The tendencies expressed in the cited literature were basically confirmed in a series of interviews undertaken by the author during an in-depth study on the development of South African labour studies, with 
sociologists at the universities of KwaZulu-Natal, Witwatersrand and Cape Town (for citations of the interviews on this topic, see Keim 2006: 382-405). This once again shows that the dimensions of marginality and underdevelopment are two separate problems, as South Africa has a considerable degree of material and institutional development.

To conclude this part on unequal personal and institutional relationships and in order to dispel any possible doubt that the afore-mentioned voices emanated from radicalised individuals, it is interesting to note that the UNESCO Report on the Social Sciences, a rather well balanced, cautious and very diplomatic document, stresses the same problems for the African continent (UNESCO 1999a: 123).

\section{Extraversion, locality and the pressure to define oneself as exotic - inequalities in the cognitive division of labour}

'Place matters only to those for whom Great Truths are not an option. The local is local for those without the power not to make it matter' (McDaniel 20003: 596). This quotation appropriately exposes the argument put forward in this paragraph. The unequal division of labour, often combined with local scientific development problems (the lack of integration into scholarly communities, isolation as well as communication infrastructure), and the prestige of institutions in the centre, have a combined effect on the cognitive level of sociological knowledge production. These factors lead to what Hountondji called 'extraversion', referring to the fact that African scholarly production is oriented neither towards the local peers nor to one's own society, but towards the overseas public (cf. the works of Hountondji). Extraversion manifests itself in the choice of research topics and in the degree of generalisation that, according to Hountondji, are oriented towards the interests of the North Atlantic audience: 'This is one of the most pernicious forms of extraversion: theoretical, or socio-theoretical extraversion, the fact that we allow the content of our scientific production, the questions we pose, and the way we deal with them to be pre-oriented, pre-determined by the expectations of our potential readers' (Hountondji 1990 b: 11).

This already points to the related problem of the local focus and limited scope of peripheral sociological production. As Alatas observed, there is a global division of labour between those who work on their own countries and those who work on countries other than their own, do comparative research and arrive at considerably higher degrees of generalisation. In accordance with extraversion, the southern social sciences limit themselves in scope and perspective. The overseas, 'international' audience is interested in (case) studies on particular societies, that in turn feed into general theory formation in the North: '(Extraversion) has to be understood as the origin of a particularly bothersome limitation in the practice of the social sciences ... the enclosure into the particular, the idea that the local scholarly discourse is only interesting if it refers to local realities, the idea that the African historian, sociologist, anthropologist, linguist, philosopher ought to do African history, African sociology, anthropology on Africa, African linguistics, African philosophy. Limiting one's own horizon in this manner, the researcher of the Third World leaves to others the theorising and the interpretation and integration into bigger entities of this mass of data he delivers. The African researcher inhibits himself the access to the universal' (Hountondji, 2001/02: 5; Translation WK). The consequences of these problems highlighted by Hountondji are further discussed below. 
The pressure to define oneself as exotic, which southern social sciences experience on an international scale, is a specific form of locality, and a particularly limiting one. As Sitas observes: ' (...) there is a serious pressure to define ourselves as "different" in the world context of ideas. Trying to be more than peripheral exotica in the "global cultural bazaar" of social science, we are bumping up against the niche trading tents we have been offered. (...) Of course, we can be cynical and say that even here very few of us are considered good enough to be included, like Ali Farka Toure and Yousso N'Dour in the category called "world music", as decorative additions' (Sitas 2006: 20).

The difference between locality and generalising abstraction can be traced empirically in the titles of publications. Typically, publications produced at the periphery contain the geographical location in their title, thus signalling the provincial or regional status of their knowledge production, a feature that has no equal in North Atlantic production. According to Baber, the conclusion from this observation is that there is a topographic dimension to social scientific knowledge production, reception and validation: '(...) a specific geography of knowledge where spatial location of the researcher and site of research also play a significant role in the reception and valorisation of the work is in operation' (Baber 2003: 618). This corresponds exactly to the quotation that marked the beginning of this subsection.

The hypothesis on the related phenomena of extraversion and locality can also be empirically tested by examining the geographical specialisation of research institutions. UNESCO's DARE-database contains information about a rather arbitrary selection of about 4,800 social sciences research institutions worldwide. The descriptions contain contact details, regular activities, publications, some key words as well as an indication of the geographical area of research. ${ }^{9}$ Similar to the data about social science journals, these can be used as a random sample. Out of the 89 African institutions contained in the database, eight made no indication of regional specialisation. Only six reached beyond the continent, whereas 33 mentioned their own country and 45 Africa or sub-regions within the continent as geographical areas. Out of the 149 Latin American social sciences institutions contained in DARE, two thirds (105) had a local or regional focus, whereas 23 focussed on other continents and 21 made no indication concerning the geographical scope of their research.

For matters of convenience, Germany and France have been selected as examples for European countries. Out of the 208 institutions ( 89 German and 119 French), 56 made no indication concerning their regional specialisation; 20 focussed exclusively on their own country and 41 on Europe; 50 on one or several other continents (often in addition to Europe), and 38 institutions indicated a global perspective. The hypothesis of the centrality of Western Europe, which in terms of knowledge dominates the rest of the world, and the marginality of Africa and Latin America, limited to local and regional research, as Hountondji criticised, is confirmed by this indicator.

However, these indicators do not show clearly to what extent the southern limitation to the local corresponds to the interests of the North Atlantic social sciences, as Hountondji purports with his concept of extraversion and Sitas with his critique of exoticism. To deal with that question, an evaluation of the activities of invited scholars at institutions in the centre might be informative. Unfortunately, systematic information on that matter is not available. However, over the course of two academic years the Ecole des Hautes Etudes en Sciences Sociales (EHESS), one of the most 
prestigious French social sciences institutions in Paris, published on its website lists with the names of all invited scholars and specifying the topics they presented at the EHESS, thus providing a valuable source for the kind of analysis required here.$^{10}$ Due to the limited number of speakers and to the fact that they were representing a variety of social sciences disciplines, the following analysis should be considered as an approximate assessment of the topic. Between 2001 and 2003, 361 visiting scholars presented their social scientific work at the EHESS. About 33 percent of them came from Western Europe, 32.5 percent from North America, 11 percent from Latin America and 7.8 percent from Africa.

The titles of their presentations at Paris give an indication of the geographical scope and degree of generalisation of their work. To demonstrate this, the totality of presentations can be categorised in an order of increasing generalisation: first, those which refer explicitly to the native country; second, those which refer to the native continent, its history or contemporary social questions; third, those that explicitly deal with France to see whether a bias has been introduced into the analysis through the location of the host institution; fourth, those that deal with other regions or eras (Ancient Rome or Greece, the Aztec or Mayan cultures, etc.); and finally those that deal with general, abstract, theoretical, methodological or epistemological questions. The scholars in the last category can be considered to have been attributed the status of scientific authorities in their respective fields by their Parisian colleagues. Those who talk about their own home country or continent, on the other side, were invited to Paris rather as informants (the term 'informant' was used by Hountondji 1994). In several cases, one presentation had to be placed into more than one category due to the complexity of the issues evoked in the title. The distribution for African scholars is represented in Table 1.

Table 1: Presentations by African scholars invited to the EHESS, 2001-2003

\begin{tabular}{|l|l|l|l|l|l|l|}
\hline \multirow{2}{*}{$\begin{array}{l}\text { Affiliation } \\
\text { of scholar }\end{array}$} & \multirow{2}{*}{ Total } & \multicolumn{3}{|l|}{ Topic of presentation relates to } \\
\cline { 3 - 6 } & & $\begin{array}{l}\text { Home } \\
\text { country }\end{array}$ & Africa & France & $\begin{array}{l}\text { Other } \\
\text { regions/ } \\
\text { times }\end{array}$ & $\begin{array}{l}\text { General } \\
\text { theory/ } \\
\text { methodol. }\end{array}$ \\
\hline Egypt & 5 & 1 & 1 & - & 3 & 2 \\
Morocco & 4 & 3 & - & - & - & 1 \\
Algeria & 4 & 3 & - & - & 1 & - \\
Ivory Coast & 3 & 1 & 2 & - & - & - \\
Tunisia & 3 & 2 & - & - & - & 1 \\
Mauritania & 2 & 1 & 1 & - & - & $?$ \\
South Africa & 2 & 2 & - & - & - & - \\
Gabon & 1 & - & - & - & - & 1 \\
Cameroon & 1 & 1 & - & - & - & - \\
Mali & 1 & 1 & - & - & - & - \\
Niger & 1 & - & 1 & - & - & - \\
Senegal & 1 & 1 & 1 & - & - & - \\
\hline Total & 28 & 16 & 6 & 0 & 4 & 5 \\
percent & 28 & 57 & 21 & 0 & 14 & 18 \\
\hline
\end{tabular}


Due to possible multiple categorisation, the sum adds up to more than 100 percent.

Source: Invited professors at the EHESS 2001/02 and 2003: http://www.ehess.fr/html/ $\mathrm{html} / 7 . h t m l$ (January 2004).

Table 1 clearly shows that the majority of African presentations concentrated on the home country of the lecturer (57 percent). Six of them related to the African continent as a whole, which means that 78.6 percent of the total would have to be considered as informants. Obviously, Africans were not invited to talk about France (0), four presentations were held on other regions than Africa, and five on general theoretical issues. It might be interesting to note that the four regional specialists were all concerned with Islam, and four out of the five presentations in the category for general theory or methodology also focussed on religion. This emphasis might be a result of the incidents on 9/11/2001 that pushed Islamic studies in the North Atlantic region. For the Latin American speakers, the distribution is illustrated in Table 2.

Table 2: Presentations by Latin American scholars invited to the EHESS, 20012003

\begin{tabular}{|l|l|l|l|l|l|l|}
\hline \multirow{2}{*}{$\begin{array}{l}\text { Affiliation } \\
\text { of scholar }\end{array}$} & \multirow{2}{*}{ Total } & \multicolumn{4}{|l|}{ Topic of presentation relates to } \\
\cline { 3 - 7 } & & $\begin{array}{l}\text { Home } \\
\text { country }\end{array}$ & $\begin{array}{l}\text { Home } \\
\text { continent }\end{array}$ & France & $\begin{array}{l}\text { Other } \\
\text { regions/ } \\
\text { times }\end{array}$ & $\begin{array}{l}\text { General } \\
\text { theory/ } \\
\text { methodol. }\end{array}$ \\
\hline Argentina & 16 & 7 & 4 & 3 & 3 & 5 \\
Brazil & 15 & 10 & 1 & 2 & 3 & 5 \\
Mexico & 6 & 6 & 1 & - & - & 1 \\
Columbia & 3 & 1 & 1 & - & 1 & - \\
Peru & 2 & 2 & - & - & - & - \\
Chile & 1 & 1 & 1 & - & - & - \\
Venezuela & 1 & 1 & - & - & - & - \\
\hline Total & 44 & 27 & 8 & 5 & 7 & 11 \\
Percent & & 61 & 18 & 11 & 16 & 25 \\
\hline
\end{tabular}

Due to possible multiple categorisation, the sum adds up to more than 100 percent.

Source: Invited professors at the EHESS 2001/02 and 2003: http://www.ehess.fr/html/ $\mathrm{html} / 7 . \mathrm{html}$ (January 2004).

Here again, the majority of the papers presented at the EHESS had a local or regional focus. The interest for France was related to comparative research between France and the native Latin American country in most of the cases. It is noteworthy that 25 percent of the presentations could be categorised as 'General Theory and Methodology'. Nevertheless, on a global scale, these results confirm the hypothesis of the marginality of African and Latin American social science. These figures can now be compared to those for North America and Western Europe as illustrated in Table 3. 
Table 3: Presentations by North-American and Western European scholars invited to the EHESS, 2001-2003

\begin{tabular}{|l|l|l|l|l|l|l|}
\hline \multirow{2}{*}{$\begin{array}{l}\text { Affiliation } \\
\text { of scholar }\end{array}$} & \multirow{2}{*}{ Total } & \multicolumn{3}{|l|}{ Topic of presentation relates to } \\
\cline { 3 - 7 } & & $\begin{array}{l}\text { Home } \\
\text { country }\end{array}$ & $\begin{array}{l}\text { Home } \\
\text { continent }\end{array}$ & France & $\begin{array}{l}\text { Other } \\
\text { regions/ } \\
\text { times }\end{array}$ & $\begin{array}{l}\text { General } \\
\text { theory/ } \\
\text { methodol. }\end{array}$ \\
\hline USA & & & & 7 & 29 & 34 \\
Italy & 75 & 11 & 5 & 2 & 8 & 17 \\
Germany & 24 & 7 & 3 & 1 & 2 & 11 \\
Spain & 14 & 9 & 1 & 1 & 1 & 4 \\
Great Britain & 10 & 1 & 1 & 1 & 5 & 4 \\
Canada & 10 & - & - & - & - & 10 \\
Switzerland & 9 & 1 & 2 & 1 & 1 & 3 \\
Greece & 8 & 4 & 1 & - & 1 & 2 \\
Portugal & 4 & 4 & 2 & - & 2 & - \\
Netherlands & 4 & - & $1-$ & - & 1 & 2 \\
Austria & 3 & & & 1 & 1 & 1 \\
Belgium & 3 & - & $1-$ & - & 1 & 1 \\
Finland & 2 & - & 1 & - & 1 & 1 \\
Sweden & 2 & - & - & - & 1 & 2 \\
Denmark & 1 & - & - & - & 1 & - \\
Norway & 1 & - & - & - & - & 1 \\
\hline Total & 203 & 40 & 27 & 14 & 55 & 93 \\
percent & & 20 & 13 & 7 & 27 & 46 \\
\hline
\end{tabular}

Due to possible multiple categorisation, the sum adds up to more than 100 percent.

Source: Invited professors at the EHESS 2001/02 and 2003: http://www.ehess.fr/html/ html/7.html (January 2004).

Almost half of all the presentations were concerned with general problems of the social sciences. Another 27 percent focussed on other regions and times, a mere 20 percent were on a topic limited to their author's home country, and another 13 percent on their home continent. To have their focus on general topics and overseas regional specialisation is particularly evident with North American guests: 45 percent of the US-American and all of the Canadian presentations concentrated on general questions. As for the Western European guests, except for the Iberian Peninsula and Greece which according to that indicator can be characterised as the European periphery very few speakers talked about their native countries. The share of presentations on other continents and times was also considerably high.

The unequal division of labour described here for one institution of the centre is also observable in the South itself. Andrade Carreño provides the counterpart to the above analysis, looking at articles in seven Mexican sociological journals with respect to the country of origin of authors and the geographical location of their object of research. He presents the results reproduced in Table 4. 
Table 4: Institutional origin and geographical location of objects of articles in Mexican social sciences journals according to Andrade Carreño

\begin{tabular}{|l|l|l|l|l|l|l|l|}
\hline \multirow{2}{*}{$\begin{array}{l}\text { Origin } \\
\text { of article }\end{array}$} & \multicolumn{6}{l}{ Geographical location of object of research } \\
\cline { 2 - 8 } & Mexico & $\begin{array}{l}\text { Lat. } \\
\text {-Amer. }\end{array}$ & $\begin{array}{l}\text { North. } \\
\text {-Amer. }\end{array}$ & Europe & $\begin{array}{l}\text { Asia } \\
\text { \& Africa }\end{array}$ & None & Total \\
\hline Mexico & 474 & 85 & 6 & 3 & 13 & 245 & 826 \\
& 57 & 10 & 1 & 0 & 2 & 30 & 100 \\
& $\%$ & $\%$ & $\%$ & $\%$ & $\%$ & $\%$ & $\%$ \\
\hline Lat.- & 0 & 121 & 0 & 0 & 0 & 38 & 159 \\
Amer. & $\%$ & 76 & 0 & 0 & 0 & 24 & 100 \\
& $\%$ & $\%$ & $\%$ & $\%$ & $\%$ & $\%$ \\
\hline North- & 32 & 25 & 7 & 1 & 0 & 44 & 109 \\
Amer. & 29 & 23 & 6 & 1 & 0 & 40 & 99 \\
& $\%$ & $\%$ & $\%$ & $\%$ & $\%$ & $\%$ & $\%$ \\
\hline Europe & 22 & 25 & 0 & 6 & 0 & 52 & 105 \\
& 21 & 24 & 0 & 6 & 0 & 50 & 101 \\
& $\%$ & $\%$ & $\%$ & $\%$ & $\%$ & $\%$ & $\%$ \\
\hline
\end{tabular}

The numbers were rounded, and consequently the percentages do not always equal exactly 100 percent.

Andrade Carreño includes the following journals, between 1980 and 1994, in his analysis: Acta Sociológica, Estudios Sociológicos, Polis Annuario de Sociología, Revista Mexicana de Sociología, Sociológica and Tiempo Sociológico.

Source: Andrade Carreño 1998: 135

The unequal division of labour is clearly observable in these figures as well. The majority of Mexican and Latin American articles focussed on the local and regional level - 57 percent and 76 percent respectively - whereas large parts of North American and European contributions were not bound geographically ( 40 percent and 50 percent respectively), Andrade Carreño is certainly right in judging this abstraction from geographical location as an indicator for general theoretical works (Andrade Carreño 1998: 136). A majority also concentrated on Mexico or Latin America, reflecting the frequent communication between southern social sciences and regional specialisations in the centre. The phenomena of extraversion and the 'captive mind' (see below) are thus detectable within the local academic communities, as the Mexican example shows.

\section{Effects of the disciplinary divisions within the social sciences}

Not only does the above mentioned indicator on the unequal division of labour among invited scholars strongly confirm the marginality of African and Latin American social sciences. Looked at more closely, the practice of inviting scholars at the EHESS also hints to another factor of marginalisation of the southern social sciences: the disciplinary structure of the social sciences that channels discourses, but also personnel and finances, and thus keeps the southern voices away from the social sciences nomothetic core disciplines (economy, sociology and political sciences). Typically, ethnology/social anthropology and orientalism are the disciplines occupied 
with societies outside of Europe, completed by 'area studies', established during the Cold War (for a slightly different focus on the disciplinary divisions as an instrument of 'internal colonisation' in the countries of the South, see Lander 2004).

An extension of the previous analysis, considering which departments of the EHESS invite speakers, reveals that an invited African social scientist most probably ends up in the Department of African Studies. In fact, out of the 38 invited Africans, 14 came to the Centre for African Studies, twelve to the Centre for Social History of Mediterranean Islam, eight to the Centre for Historical Research, one to the Centre for Turkish History, one to the unit of Sociology, History, Anthropology and Cultural dynamics, one to the Laboratory for Social Anthropology, and one to the Division of Area Studies. This means that in the majority, invited African scholars related to regional specialists, not to general social scientists. The same disciplinary channelling mechanisms that keep southern social scientific production from the core of the business impact, for example, on their publishing opportunities. Regionally specialised journals are more readily available to sociologists from the South than more prestigious general social sciences journals (see the interview passages cited in Keim forthcoming $b$ on this subject). As a consequence, their contributions remain largely invisible for the northern and international community of peers in their own discipline.

\section{Evolutionism in social thinking}

Finally, marginality is also related to the inherent evolutionist thinking in the social sciences, which - despite post-modern deconstruction and disillusion - still prevails and creates hierarchies between objects of research as well as between locations of sociological production. The assumption that all regions and societies will go through the same stages of development, with the rich nations of the North actually representing the peak of human development and the rest of the world 'catching up', also affects the perception of social scientific production from the north Atlantic domain. In the South, it inhibits 'methodological non-alignment', i.e. alternative grounds for thinking and theorising about local social developments: ' $(. .$.$) it is$ expected that other parts of the world develop in the same manner as the modern Western world (...). It is a matter of time and stages. (...) The development of the nonWestern world is considered as parallel to that of the West. The captive mind does not consider another possible alternative, that is, methodological non-alignment' ( $\mathrm{S}$. H. Alatas 1974: 695).

The core disciplines do not consider Africa or Latin America as places with their own social realities and with genuine theory building, but instead as a field, a case study or a laboratory, where 'universal theory' developed out of the North Atlantic experience can be tested and validated. This attitude is expressed strongly in the publication Africa and the disciplines - the contributions of research in Africa to the social sciences and humanities (Bates/Mudimbe/O'Barr 1993). Contrary to its title, that pretends to focus on the contribution of research in Africa to the development of the disciplines, the book contains a series of articles illustrating the importance of research on Africa, for example in the field of economy: 'Africa is a gold mine to economists, because its economic history has been so extreme. Booms, busts, famines, migrations. Because there are so many African countries, often following radically 
different economic policies, Africa offers a diversity ideally suited to the comparative approach which is the economist's best substitute for the controlled experiment' (Collier 1993: 58). This passage clearly reveals to what extent Africa is thought of as a field of experimentation, as a region exporting raw data in order to complement universal theory done in the North - a gold mine. This perception is intimately connected to the evolutionist assumption that Africa trails far behind in its social development and thus cannot yield cutting edge research in the social sciences. Among sociologists in the South, this provokes the strong feeling that they could not contribute anything new and meaningful to international debates, because their own realities are too far behind the latest developments in the metropolises. This is expressed by Johann Marée in an interview passage about the lack of interest for South African sociologies abroad: '(...) it is because they are the vanguard of development, they don't have anything to learn from us here. We can't inform them on the questions they are dealing with now' (Johann Marée, Interview 3.3.2004). In this regard, recent debates about modernity in the South and the North seem to be of particular importance (Dussel 2003; Lander 1997, 2003, 2004; Mignolo 2004). These might contribute to a necessary paradigm shift to counter the detrimental impact of evolutionism.

\section{The consequences of marginalisation - a critical conclusion}

The results strongly confirm the persisting marginalisation within sociology and the social sciences internationally at a macro-sociological, world-scale level. They should thus be taken seriously in any debate about the internationalisation or globalisation of sociology. Any assumptions of an integrated, homogeneous, international or global community of equals seem to be premature and lacking reflection on the distortions within international sociology. The results obtained through the above empirical analyses should be taken seriously with regard to two more far-reaching issues: with regard to science policy in the South; and with regard to the debates generated by recently emerging theoretical attacks against North Atlantic domination and by claims for the possible globalisation of the discipline. The latter also points to recent challenges to the very epistemological foundations of sociology.

Considering the results presented above, it should be stressed that recent developments in science and research policy are not appropriate for overcoming the centre-periphery structures in the social sciences. Individual evaluation against socalled 'international standards' and, most of all, the pressure to 'publish internationally or perish', again push sociologists at the periphery to turn their back on their own local scholarly communities and on their own societies in general, obliging them to publish according to the rules and preferences of the so-called 'international' audience. Especially for the domain of the social sciences, the policy of 'catching up' with the international mainstream is not an option (a proponent of 'catching up' for peripheral scholarly communities is Gaillard: Gaillard 1987, 1994; Gaillard/Schlemmer 1996). The generation of sociological knowledge follows a different logic than, for instance, the natural sciences. In particular the lower level of abstraction from the specific context of emergence of social science knowledge requires different strategies in science policy to overcome intellectual dependency and to allow for the development of autonomous traditions. A more complete argument for counter-hegemonic currents cannot be fully expressed here. ${ }^{11}$ 
Concerning the current internal debates, in recent years several theoretical attacks have been launched against the North Atlantic domination over the social sciences that cannot be accounted for through macro-social, quantitative analysis at a global scale: criticism of Euro-centrism (Amin 1988, Fals-Borda/Mora-Osejo 2003), deconstruction of orientalism (Said 1978), attacks on anthropology and area studies (Mamdani 1997, Mafeje s.d.) and the attempt to 'provincialize Europe' (Chakrabarty 2000). S. F. Alatas (2001) has conceptualised to what extent imported approaches may be irrelevant for the analysis and understanding of local societies, and has proposed a set of criteria necessary to render southern sociologies more relevant to their own contexts. At the same time, the constructive approach of the indigenisation project attempts to develop sociological concepts from social knowledge contained in oral poetry (Akiwowo 1986, 1999, Makinde 1988, Lawuyi and Taiwo 1990, for a critical review see Adésínà 2002; Keim 2007).

These approaches have contributed to opening up spaces for a critical discussion of the established Northern dominated theories. ${ }^{12}$ They have furthered a critical reception and diversified reaction to the globalisation debate within the discipline. The subsequent discussion shows that the results of this paper should not be taken as highlighting an exclusive development problem of sociologies in the global South. On the contrary, the centre-periphery structures affect the very epistemological foundations of the discipline as a whole (for a detailed version of the argument, see Connell 2006, Keim forthcoming a).

In particular, the dimension of marginality and centrality leads to topographical hierarchies in sociological knowledge production. This poses a fundamental problem to the constitution of a nomothetic discipline that aims at making universally valid assumptions on social realities. In the past as well as today, the dominant North Atlantic tradition has exerted hegemonic tendencies of Eurocentric inclusion and exclusion, leading to a distorted form of universalism. Ethnocentrically, it emanated from North Atlantic particular social conditions; logocentrically, it deduced common general assumptions, based on these particular conditions, and applied them to all social realities on the globe. Thus, a specific form of Eurocentrism has 'miraculously encountered the particular own in the general and the general in the particular own' (Waldenfels 1997: 49).

The majority of humankind, its social experience and social scientific reflection on that experience, are excluded from sociological theory formation through the observed marginalisation tendencies, but are included into the scope of general theories derived from the particular North Atlantic experience. The problem of centre and periphery is thus not only an obstacle to the autonomous development of sociologies in the global South, but an epistemological problem at the very core of the discipline. Up to date, few are those who have recognized the epistemological challenge to the discipline emanating from the South in recent years (Berthelot 1998, Connell 2006).

Many of the classical approaches (for a critical discussion, see Connell 1997), have thus formulated universalistic aspirations without reflecting their particular social location. Their universalism, however, is based on the meta-theoretical assumption of the unicity of humankind (Archer 1991:131). Some of the Southern critiques, on the contrary, deny or at least question this ontology: 'This is precisely the problem. The "unicity of humanity" that requires that we have "a single discipline" for "a single 
world" is in the imagination of the conventional western sociologist' (Adésínà 2002: 93). Ontological and subsequently sociological universalism appears to be at the origin of recent calls for the internationalisation or globalisation of the discipline. These are interpreted by Adésínà and others as hiding new attempts of North Atlantic domination.

Their scepticism seems to be justified, for instance, by one of the publications that actually tries to further the internationalisation of the discipline. Albrow/King (1990), in their introduction to a collection of articles from International Sociology, propose a periodization in which the phase of indigenization is at least implicitly considered to be already overtaken by the last phase, globalisation of sociology. This shortcutting of the necessary debate around alternative sociologies originating at the periphery is seen by critical scholars as, for instance, Oommen, as a new version of classical universalism and thus as yet another 'camouflage' of North Atlantic domination: '(...) one can speak of internationalization of sociology as an ongoing process of modernization/ Westernization of sociology' (Oommen 1991:71).

These debates are situated, in the end, at the level of meta-theory, ontology and philosophy. What can be concluded, however, from the above presented empirical data on the state of international sociology, is that the discussion can hardly be called a serious scholarly discussion, in the sense of a debate among equals where the better argument counts, as long as communication structures remain as heavily distorted as they are up to date.

\section{Notes}

1. This paper is based on results of my PhD thesis (Keim 2006). The book based on the thesis will appear later in 2008 (Keim forthcoming b).

2. For a critical assessment of the construction of 'classical theory' and of the 'founding fathers', see Connell 1997.

3. The analogy ends, at latest, when it comes to one of the fundamental assumptions of economic dependency theory, namely that the development in the centre causally determines underdevelopment in the periphery. This can in no way be assumed for the domain of the social sciences.

4. Social Science Citation Index, http://www-fr.redi-bw.de/session/SSCI-4667830f.html, (Jan. 2006). The online resources of Freiburg University provide access to the years 19921997.

5. FRANCIS, INIST-CNRS, 2001. http://www.bibliothek.uni-regensburg.de/dbinfo/ einzeln.phtml?bib_id=alle\&titel_id=656(Jan. 2005).

6. According to the UNESCO Statistical Yearbook 1999, Table IV.5 'Book production: number of titles by UDC classes'.

7. www.latindex.org (Auf. 2006). Unfortunately, this database was still in an early phase of establishment at the time of data collection for the analyses presented in this paper and could not be used.

8. This corresponds to the division of labour between senior and junior researchers that Shinn observes at the micro-level within scientific institutions. Cf. Shinn 1988.

9. The fact that 'geographic area' is a feature included in the form the contacted institutions were supposed to deliver to UNESCO poses a problem insofar as this suggests giving such an indication, whereas the questions of abstraction, empirical or theoretical research, were probably not included. No indication of geographical specialisation may thus mean either the omission of the question, a global scope or an abstract, theoretical orientation. 
10. The EHESS published lists of invited speakers for the years 2001/02 and 203 on its website (http://www.ehess.fr/html/html/7.html, Jan. 2004). Data for the following years were not available any more.

11. I have argued that sociological innovations, what I termed 'counter hegemonic currents', might rather be expected to emerge out of locally grounded communities. Their socially relevant research practice, in the course of their development and maturation, leads to increasingly theoretically relevant research output. An in-depth case study on the historical and recent developments in South African labour studies adequately illustrates how, under specific social and political historical circumstances, a locally relevant domain of sociological research did emerge and favoured growing independence from North Atlantic domination (see Keim forthcoming b: 167-503). The concept of 'counter-hegemonic current' thus relates to the emergence of original, growingly autonomous sociologies at the periphery.

12. However, these reclamations from the global South have been of a rather limited impact on de facto relationships within the international community. I have pointed out elsewhere (Keim 2006) the three main reasons for this: first, restricting themselves to the scope of theories and texts, they have not aimed at the principal media of domination highlighted in the above analyses, i.e. institutions and funding. The second reason is related to the problem of marginalisation. In fact, North Atlantic domination over the field of social sciences relies on the shared acceptance of a common arena of competition (for the concept of 'arena' see Shinn 2000). Only if one accepts that the institutions and communication media of the dominant mainstream are the arena of competition in one's discipline, then the battle for international scholarly reputation can begin and marginalising tendencies be put into operation. Formulating their explicit assault on North Atlantic domination, the theoretical critiques in question stepped into the same arena of competition for international recognition, trusting that their voices would be heard and their arguments taken seriously by the dominant northern audience. Finally, their claims met ignorance in a general climate of theoretical and epistemological post-modern laissez-faire.

\section{References}

Adebowale, Sulaiman A., 2001, 'The scholarly journal in the production and dissemination of knowledge on Africa: exploring some issues for the future', African Sociological Review, Vol. 5, No. 1:1-16.

Adésínà, Jìmí, 2002, 'Sociology and Yoruba studies: epistemic intervention or doing sociology in the 'vernacular"?, African Sociological Review, Vol. 6, No. 1:91-114.

Akiwowo, Akinsola A., 1980, 'Trend Report: Sociology in Africa Today', Current Sociology, Vol. 28, No. 2: 1-165.

Akiwowo, Akinsola A., 1986, 'Contributions to the sociology of knowledge from an African oral poetry', pp. 103-117 in Martin Albrow/ Elizabeth King, eds., Globalization, knowledge and society: readings from International Sociology, London.

Akiwowo, Akinsola A., 1999, 'Indigenous sociologies - extending the scope of the argument', International Sociology, Vol. 14, No. 2:115-138.

Alatas, Syed Farid, 2001, 'The study of the social sciences in developing countries: towards an adequate conceptualisation of relevance', Current Sociology, Vol. 49, No. 2, March: 1-27.

Alatas, Syed Farid, 2003, 'Academic dependency and the global division of labour in the social sciences', Current Sociology, Vol. 51, No. 6: 599-613.

Alatas, Syed Hussein, 1974, 'The captive mind and creative development', International Social Science Journal, Vol. XXVI, No. 4: 691-700. 
Alatas, Syed Hussein, 2006a, 'The idea of autonomous sociology-reflections on the state of the discipline', Current Sociology, Vol. 54, No. 1: 5-6.

Alatas, Syed Hussein, 2006b, 'The autonomous, the universal and the future of sociology', Current Sociology, Vol. 54, No. 1: 7-23

Albrow, Martin and Elizabeth King, eds., 1990, Globalization, knowledge and society: readings from International Sociology, London.

Altbach, Philip G., ed., 1991, Publishing and development in the Third World, London.

Amin, Samir, 1988, L'eurocentrisme, Paris.

Andrade Carreño, Alfredo, 1998, La sociología en México: temas, campos científicos y tradición disciplinaria, (Sociology in Mexico: themes, scientific fields and disciplinary tradition), México.

Archer, Margaret S., 1990, 'Foreword', pp.1-2 in Martin Albrow and Elizabeth King, eds., Globalization, knowledge and society: readings from International Sociology, London.

Archer, Margaret S., 1991, 'Sociology for one world: unity and diversity', International Sociology, Vol. 6, No. 2: 131-147.

Arunachalam, Subbiah, 1996, 'Science on the periphery enriches mainstream science, but at what cost? The case of ethnobotany', pp. 29-50 in Waast, Roland, ed., Les sciences au sudétat des lieux, (The sciences in the South - recent trends), Vol. 6 of Les sciences hors d'Occident au XXe siècle (The sciences out of Occident in the 20th century), Paris.

Arvanitis, Rigas and Gaillard, Jacques, eds., 1992, 'Science indicators in developing countries', Proceedings of the international conference on science indicators in developing countries, ORSTOM/CNRS, Paris, UNESCO, 15.-19. October 1990, Paris.

Baber, Zaheer, 2003, 'Provincial universalism. The landscape of knowledge production in an era of globalization', Current Sociology, Vol. 51, No. 6: 615-623.

Barré, Rémi; Papon, Pierre, 1993, Economie et politique de la science et de la technologie (Economy and politics of science and technology), Paris.

Bates, Robert H., Mudimbe, V.Y., and O'Barr, Jean, eds., 1993, Africa and the disciplines - the contributions of research in Africa to the social sciences and humanities, Chicago, London.

Berthelot, Jean-Michel, 1998, 'Les nouveaux défis épistémologiques de la sociologie', (New epistemological challenges to sociology), Sociologie et Sociétés, Vol. XXX, No. 1: 1-16.

Cabral, Amilcar, 1973, Revolution in Guinea: an African struggle, selected texts, London.

Cabral, Amilcar, 1983, Die Theorie als Waffe: Schriften zur Befreiung in Afrika, edited by Amilcar-Cabral-Gesellschafte.V., Bremen.

Cardoso, Fernando Henrique and Faletto, Enzo, 1969, Dependencia y Desarollo en America latina, (Dependency and development in Latin America) Paris.

Chakrabarty, Dipesh, 2000, Provincialising Europe - postcolonial thought and historical difference, Princeton.

Chekki, Dan A., 1987, 'Synthesis and Indigenization in Indian sociology beyond tradition', pp. 1665-1698 in Hallen, G. C., ed., Sociology in India-perspectives and trends, Volume IV, Meerut, 1990-91.

Collier, Paul, 1993, 'Africa and the study of economics', pp. 58-82 in Bates, Robert H., Mudimbe, V.Y., O'Barr, Jean, eds., Africa and the disciplines - the contributions of research in Africa to the social sciences and humanities, Chicago, London.

Connell, R. W., 1997, 'Why Is Classical Theory Classical?', The American Journal of Sociology, Vol. 102, No. 6: 1511-1557. 
Connell, R. W., 2006, 'Northern theory: the political geography of general social theory', Theory and Society, Vol. 35 No. 2: 237-264.

Dussel, Enrique, 2003, 'Europa, modernidad y eurocentrismo', (Europe, modernity and eurocentrism), pp. 41-54 in Lander, Edgardo, ed., La colonialidad del saber: eurocentrismo $y$ ciencias sociales - perspectivas latinoamericanas, (The coloniality of knowledge: eurocentrism and the social sciences), Buenos Aires.

Fals-Borda, Orlando and Luis E. Mora-Osejo, 2003, 'Context and diffusion of knowledge - a critique of Eurocentrism', Action Research, Vol. 1, No. 1:29-37.

Fanon, Frantz, 1961, Les damnés de la terre, Paris.

Fanon, Frantz, 1968, Sociologie d'une révolution: l'an 5 de la révolution algérienne, Paris.

Frame, Davidson, 1985, 'Problems in the use of literature-based S\&T indicators in developing countries', pp. 117-121 in Morita-Lou, Hiroko, ed., Science and technology indicators for development, Proceedings of the Panel of Specialists of the United Nations Advisory Committee on Science and Technology for Development, Graz, Austria, 2-7 May, 1984, London.

Gaillard, Jacques, 1987, 'Les chercheurs des pays en développement - origines, formations, et pratiques de la recherche', (Researchers in developing countries - origins, education and research practice), DEA thesis at the Conservatoire National des Arts et Métiers 1986, Paris.

Gaillard, Jacques, 1994, 'La Naissance difficile des communautés scientifiques', (The difficult birth of scientific communities), pp. 213-251 in Salomon, Jean-Jacques; Francisco Sagasti, Celine Sachs-Jeantet, eds., The uncertain quest - science, technology and development, Tokyo, New York, Paris.

Gaillard, Jacques, ed.,1996, Coopérations scientifiques internationales (International scientific cooperations), Orstom, Paris.

Gaillard, Jacques, 1999, La coopération scientifique et technique avec les pays du Sud-peut-on partager la science? (Scientific and technical cooperation with the countries of the Southcan science be shared?), Paris.

Gaillard, Jacques and Schlemmer, Bernard, 1996, 'Chercheurs du Nord, chercheurs du Sud: itinéraires, pratiques, modèles: un essai d'analyse comparative', (Researchers from the North, researchers from the South: careers, practice, models: a tentative comparative analysis), pp. 113-137 in Waast, Roland, ed., Les sciences au sud-état des lieux (Sciences in the South - trend report), Vol. 6 of the series Les sciences hors d'Occident au XXe siècle (The sciences out of Occident in the 20th century), Orstom, Paris.

Gareau, Frederick H., 1985, 'The multinational version of social science with emphasis upon the discipline of sociology', Current Sociology, Vol. 33, No. 3: 1-165.

Genov, Nikolai, 1991, 'Internationalization of sociology: the unfinished agenda', Current Sociology, Vol. 39, No. 1:1-20.

González Casanova, Pablo, 1968, 'Las ciencias sociales' (The social sciences), pp. 1-44 in González Casanova, Pablo, Bonfil, Guillermo, Las ciencias sociales y la antropología-dos ensayos (The social sciences and anthropology - two essays), México.

Hountondji, Paulin, 1990a, 'Recherche et extraversion: éléments pour une sociologie de la science dans les pays de la périphérie', (Research and extraversion: elements for a sociology of science for the countries of the periphery), Africa Development, Vol. XV, Nos. 3/4: 149158.

Hountondji, Paulin, 1990b, 'Scientific dependence in Africa today', Research in African Literatures, Vol. 21, No. 3: 5-15. 
Hountondji, Paulin, 1994, 'Démarginaliser', (Demarginalise), in Hountondji, Paulin, ed., Les savoirs endogènes (Endogenous knowledge), CODESRIA: 1-37.

Hountondji, Paulin, 2001/02, 'Le savoir mondialisé: déséquilibres et enjeux actuels', (Globalised knowledge: imbalances and actual challenges), Conference on 'La mondialisation vue d'Afrique' (Globalization from an African perspective) at the University of Nantes/Maison des Sciences de l'Homme Guépin, Academic Year 2001/02, www.mshalpes.prd.fr/guepin/afrique/charpar/cfpaulin.pdf(download Oct. 2003).

Ibn Khaldun, 1967-68, Discours sur l'Histoire universelle Al-Muqaddima, ed. by Vincent Monteil, Beyrouth.

Keim, Wiebke, 2006, Vermessene Disziplin. Nordatlantische Dominanz und konterhegemoniale Strömungen in der Entwicklung afrikanischer und lateinamerikanischer Soziologien, (North-Atlantic domination and counter-hegemonic currents in the development African and Latin American sociologies, working title) PhD Thesis, University of Freiburg and Paris IV-Sorbonne, August.

Keim, Wiebke, 2007, 'Jenseits von Afrika - Auseinandersetzungen um den Hegemonialanspruch der, Internationalen Soziologie', (Out of Africa - Discussions on hegemonic tendencies, International Sociology'), in Sabine Ammon et al., 2007, eds., Wissen in Bewegung - Vielfalt und Hegemonie in der Wissensgesellschaft (Knowledge in movement - diversity and hegemony in the knowledge society), Göttingen: 121-139.

Keim, Wiebke, Forthcoming a, 'Distorted universality - internationalization and its implications for the epistemological foundations of the discipline', Canadian Journal of Sociology.

Keim, Wiebke, Forthcoming b, 'Vermessene Disziplin. Zum konterhegemonialen Potential afrikanischer und lateinamerikanischer Soziologien', (Distorted discipline. On the counterhegemonic potential of African and Latin American sociologies), transcript, Bielefeld.

Koyano, Shogo, 1976, 'Sociological studies in Japan - pre-war, post-war and contemporary stages', Current Sociology, Vol. 24, No. 1.

Krishna, V. V., 1992, "The colonial "model" and the emergence of national science in India, 1876-1920', in Petitjean, Patrick; Catherine Jami and Anne Marie Moulin, Science and empires. Historical studies about scientific development and European expansion, Dordrecht: 57-72.

Lander, Edgardo, 1997, 'Modernidad, colonialidad y postmodernidad', (Modernity, coloniality and postmodernity) Revista Venezolana de Economía y Ciencias Sociales (Venezuelan Journal of Economy and Social Sciences), No. 4: 1-14 (http://ladb.unm.edu/econ/ content/ecosoc/indice/, downloaded Nov. 2005).

Lander, Edgardo, ed., 2003, La colonialidad del saber: eurocentrismo y ciencias sociales perspectivas latinoamericanas (Coloniality of knowledge: eurocentrism and the social sciences - Latin American perspectives), Bueno Aires.

Lander, Edgardo, 2004, 'Universidad y producción de conocimiento: reflexiones sobre la colonialidad del saber en América Latina', (University and the production of knowledge: reflections on the coloniality of knowledge in Latin America), pp. 167-179 in Sánchez Ramos, Irene; Raquel Sosa Elízaga, eds., América Latina: los desafios del pensamiento crítico (Latin America: challenges for critical thinking), México.

Lawuyi, O.B. and Olufei Taiwo, 1990, 'Towards an African sociological tradition: a rejoinder to Akiwowo and Makinde', pp. 135-151 in Martin Albrow and Elizabeth King, eds., Globalization, knowledge and society: readings from International Sociology, London.

Lie, John, 1996, ‘Sociology of contemporary Japan', Current Sociology, Vol. 44, No. 1: 1-66. 
MacLeod, R., 1982, 'On visiting the moving metropolis: reflections on the architecture of imperial science', Historical Records of Australian Science, Vol. 5, No. 3: 1-16.

Mafeje, Archie, n.d., 'Anthropology in post-independence Africa: end of an era and the problem of self-definition', Multiversity of the MultiWorld Network, Malaysia. http://www.multiworld.org/m_versity/articles/article.htm, (download Sept. 2005).

Magubane, Bernard Makhosezwe, 1983, 'Towards a sociology of national liberation from colonialism. Cabral's legacy', in Magubane, Bernard Makhosezwe, African sociology towards a critical perspective, Trenton, New York, Asmara, 2000: 377-403.

Makinde, A. Akin, 1988, 'Asuwada principle: an analysis of Akiwowo's contributions to the sociology of knowledge from an African perspective', pp. 119-134 in Martin Albrow and Elizabeth King, eds., Globalization, knowledge and society: readings from International Sociology, London.

Mamdani, Mahmood, 1997, 'Africa and 'African Studies', pp. 149-154 in Cloete, Nico et al., eds., Knowledge, identity and curriculum transformation in Africa, Cape Town.

McDaniel, Susan A., 2003, 'Introduction: the currents of sociology internationally preponderance, diversity and division of labour', Current Sociology, Vol. 51, No. 6: 593597.

Mignolo, Walter, 2004, 'Colonialidad global, capitalismo y hegemonía epistémica' (Global coloniality, capitalism and epistemic hegemony), pp. 113-137 in Sánchez Ramos, Irene and Raquel Sosa Elízaga, eds., América Latina: los desafíos del pensamiento crítico (Latin America: challenges for critical thinking), México.

Mkandawire, Thandika, 1989, 'Problems and prospects of the social sciences in Africa', Eastern Africa Social Science Research Review, Vol. V, No. 1: 1-12, http://www.ossrea.net/eassrr/ jan89/ thandi.htm (download Aug. 2005).

Oommen, T. K., 1991, 'Internationalization of sociology: a view from developing countries', Current Sociology, Vol. 39, No. 1:67-84.

Petitjean, Patrick; Jami, Catherine, Moulin, Anne Marie, 1992, Science and empires. Historical studies about scientific development and European expansion, Dordrecht.

Polanco, X., 1985, 'Science in developing countries: an epistemological approach on the theory of science in context', Quipu, Vol. 2 No. 2: 202-218.

Polanco, Xavier, 1990, 'Une science-monde: la mondialisation de la science européenne et la création de traditions scientifiques locales', in Polanco, Xavier, ed., Naissance et développement de la science-monde - production et reproduction des communautés scientifiques en Europe et en Amérique latine (Origin and development of world-science the production and reproduction of scientific communities in Europe and Latin America), Paris: 10-52.

Polanco, Xavier, 1992, 'World-Science: How is the history of world-science to be written?', pp. 225-242 in Petitjean, Patrick; Catherine Jami, Anna Marie Moulin, eds., Science and empires. Historical studies about scientific development and European expansion, Dordrecht.

Pouris, Anastassios, 1995, 'Mapping of social sciences and arts and humanities research in South Africa, 1981-1993', Consultancy for the ARHS Programme, Human Sciences Research Council, Pretoria.

Rashed, Roshdi, 1992, 'Science classique et science moderne à l'époque de l'expansion de la science européenne', in Petitjean, Patrick; Catherine Jami, Anne Marie Moulin, Science and empires. Historical studies about scientific development and European expansion, Dordrecht: 19-30. 
Romani, Vincent, 2008, 'Sciences sociales et coercition. Les social scientists des Territoires palestiniens entre lutte nationale et indépendance scientifique', PhD thesis, Université Paul Cézanne-Aix-Marseille III.

Sagasti, Francisco R., 1978-79, 'Towards an endogenous scientific and technological development for the Third World', Alternatives, IV: 301-316.

Said, Edward W., 1978, Orientalism.

Saldaña, Juan-José, 1992, 'Science et pouvoir au XIXe siècle - la France et le Mexique en perspective', in Petitjean, Patrick; Catherine Jami, Anne Marie Moulin, Science and empires. Historical studies about scientific development and European expansion, Dordrecht: 153-164.

Schubert, András; Braun, Tibor, 1996, 'Scientopography - world maps and charts based on scientometric indicators. A bird's eye view on the metropolis and beyond', pp. 65-72 in Waast, Roland, ed., Les sciences au sud-état des lieux, (The sciences in the South-recent trends), Vol. 6 of Les sciences hors d'Occident au XXe siècle (The sciences out of Occident in the 20th century), Orstom, Paris.

Shinn, Terry, 1988, 'Hiérarchies des chercheurs et formes de recherches', (Hierarchies between researchers and forms of research), Actes de la Recherche en Sciences Sociales, Vol. 74: 222.

Shinn, Terry, 2000, 'Axes thématiques et marchés de diffusion. La science en France, 19751999', (Thematic axes and diffusion markets: Science in France, 1975-1999) Sociologie et Société, Vol. XXXII, No. 1:43-69.

Sitas, Ari, 2006, 'The African Renaissance challenge and sociological reclamations in the South', Current Sociology 54 No. 3: 357-380, http:/gsp.soziologie.unifreiburg.de/ gspdat/people/sitas/seminarfreiburg-2002/africanrenaissance.pdf. (Oct 2005).

Szanton, David L., and Sarah Manyika, 2002, 'PhD Programs in African Universities: Current Status and Future Prospects', Paper commissioned by the Rockefeller Foundation, Institute of International Studies and Center for African Studies, University of California, Berkeley, http://ias.berkeley.edu/africa/Research/AfricanPhDCover_Report_Ref.pdf (download November 2003).

Tamari, Salim, 1994, 'Problems of social science research in Palestine: an overview', Current Sociology, Vol. 42, No. 2: 67-86.

Teferra, Damtew, 2002, 'Scientific communication in African universities - the role of external agencies', pp. 134-154 in Mouton, Johann, Waast, Roland, Ritchie, F., eds., 'Science in Africa - Proceedings of a symposium held on 17 \& 18 Oct. 2001 in Somerset West, South Africa, University of Stellenbosch'.

Todd, J., 1993, 'Science in the periphery: an interpretation of Australian scientific and technological dependency and development prior to 1914', Annals of Science, Vol. 50: 3336.

UNESCO, 1999a, 'The social sciences in sub-Saharan Africa', pp 122-128 in UNESCO, World social science report, Paris.

UNESCO, 1999b, Statistical Yearbook.

Waast, Roland, ed., 1996, Les sciences au sud-état des lieux (The sciences in the South - recent trends), Vol. 6 of Les sciences hors d'Occident au XXe siècle (The sciences out of Occident in the 20th century), Orstom, Paris.

Waast, Roland, 2001, 'Afrique, vers un libre marché du travail scientifique?', (Africa, towards a free market of scientific labour?), Economies et Sociétés, Série F, Vol. 39, Nos. 9-10: 13611413. 
Waast, Roland, 2002, 'Science in Africa: an overview', pp. 37-61 in Mouton, Johann, Waast, Roland, Ritchie, F., eds., 'Science in Africa-Proceedings of a symposium held on 17 \& 18 Oct. 2001 in Somerset West, South Africa, University of Stellenbosch'.

Waast, Roland and Gaillard Jacques, eds., 1996, Coopérations scientifiques internationales (International scientific cooperation), Vol. 7 of Les sciences hors d'Occident au XXe siècle (The sciences out of Occident in the 20th century), Orstom, Paris.

Waldenfels, Bernhard, 1997, Topographie des Fremden (Topography of the Other), Frankfurt/ Main.

Weingart, Peter, 2004, 'Knowledge and Inequality', unpublished document, University of Bielefeld.

\section{W. Keim}

Institut für Soziologie der Universität Freiburg Vaubanallee 2

79100 Freiburg

Germany 